\title{
The Significance of Career for Individuals
}

KEYWORDS

career, profession, human being, job market

\begin{abstract}
Professional career has become an increasingly frequently chosen subject of theoretical research based on numerous sciences, such as psychology, sociology, economics, pedagogy, and management. Constantly emerging, new theories of professional development provide a new perspective on this issue. A plethora of contemporary transformations obliges an individual to take responsibility for his or her own professional biography. If every person carries out a career, regardless of its quality, and if that career lasts for the person's whole lifetime, both throughout the period of professional activity and the time of preparation preceding it, one can presume that the choice of career requires reflection and in-depth conceptual considerations, which proves its significance for the subject.
\end{abstract}

The nature of quality transformations of the world, expressed in its permanent creation, is becoming the reason behind the difficulty in the unambiguous definition of meanings assigned to career both by the society and by an individual participating in it. Contemporary reality undoubtedly favours the shaping of "individually developed and updated strategies that must be adequate to the pace of changes occurring in the world." These conditionings are also noteworthy for the individual's professional life, and therefore, also for the career he or she is pursuing. The individual becomes the "manager" of his or her own growth, responsible for its progress.

The importance of career is also proven by the progressing development of various fields and specialisations of analysing professional growth, such as: professional counselling, career guidance, ${ }^{2}$ career counselling, human resources management, career management, ${ }^{3}$ work psychology, organisational psychology,

\footnotetext{
1 A. Cybal-Michalska, The World in Which "Career Has a Career" - the World of Satisfaction with Career and Professional Success, "Studia Edukacyjne," No. 26, 2013, pp. 19-38.

2 M. Suchar, Career Models. Predicting the Next Step, Warszawa 2010, p. 9.

3 Vide: M. Amstrong, Human Resources Management, Kraków 2005.
} 
coaching, mentoring, or notions found in English-language sources related to the fields dealing with the analysis of professional development: career psychology, counselling psychology, vocational psychology, ${ }^{4}$ occupational psychology or counsellogy. What is steadily increasing is the need for professional counselling services, which in turn results in the development of the counselling-related discourse known as counselling boom. ${ }^{5}$ The central object of interest of the abovementioned specialisations is career, and in particular the process of its planning, monitoring and management, both in the organisational and individual dimension. "The wish to guarantee oneself square-sure existence in a world full of unpredictable events" 6 requires an in-depth reflection supported with specialist knowledge. In fact, career is not only of considerable social importance (it affects the development and existence of the society), but it has also individual significance (in that it shapes the feeling of satisfaction, success, quality of life), which is why it is increasingly becoming the object of research and academic interest.

The focus of the contemporary society on diversity contributes to the change in the meanings assigned to career. An important feature of this phenomenon is including career among the most precious and appreciated social values. ${ }^{7}$ What is more, as A. Bańko claims, "one of the most basic development tasks of an individual is related to the preparation for a career, and one of the basic life tasks is doing a job and professional activity." ${ }^{\text {T }}$ The reasons behind such a situation are to be found in the increased significance of knowledge and information, which is expressed in the popular notion of lifelong learning. A contemporary individual focuses on permanent development, because the bulk of individual knowledge defines the social position of a person and gratifications that follow from it. This is the mechanism that shapes the competitiveness on the job market. Furthermore, "the

\footnotetext{
${ }^{4}$ Vide: W.B. Walsh, M.L. Savickas, P.J. Hartung, Handbook of Vocational Psychology. Theory, Research, and Practice, $4^{\text {th }}$ Edition, Routledge, United Kingdom 2013.

${ }^{5}$ A. Kargulowa, About the Theory and Practice of Counselling. Varieties of Counselling Discourse, Warszawa 2007, p. 9.

${ }^{6}$ W. Lanthaler, J. Zugmann, ME Campaigne. A New Way of Thinking About Career, Warszawa 2000, s. 10.

${ }^{7}$ Vide: W. Duda, D. Kukla, A Career in the Face of Progressing Transformations at Work, Częstochowa 2010, p. 39.

K. Słomczyński, Career and Success. Sociological Analyses, Zielona Góra 2007, G. Bartkowiak, Orientation Towards Development and Learning of Employees in Organisation, Poznań 1998.

E. Kasprzak, The Sense of Quality of Life for Employees with Different Career Patterns, Bydgoszcz 2013, K. Klimkowska, Orientation Towards Professional Success of Students Graduating from Translation Studies, Lublin 2013.

${ }^{8}$ A. Bańka, The Quality of Life in Psychological Experience of Everyday Life Related to Professional Development, Work and Unemployment, [in:] A. Bańka, R. Derbis (eds), Measuring and Experiencing the Quality of Life in the Employed and the Unemployed, Poznan - Częstochowa 1995, p. 10.
} 
significant social role of the career follows from the notion that the 'upward movement' inherent in it is combined with a definite, attractive and tempting ideology of success." "An important motivator for an individual, which encourages people to achieve professional success, are both objective and subjective indicators. An example of the former may be: the social position, specific competences, skills, responsibilities, roles, activities and professional decisions, whereas the latter refer to the individual interpretation of work-related events (aspirations, expectations, values, needs, satisfaction and the feelings related to professional experiences). ${ }^{10}$

Z. Baumann claims that career started to be considered from individual perspective in the period of capitalism, or when "the individual became lonely as opposed to the society and it had to use its own work and effort to make a place for itself in the society" "11. Only in such reality can each person have a chance to be successful, because no position is inherently assigned by birth. People have a wish to "live their own lives," which is expressed in the capability of making autonomous decisions. " ${ }^{12}$ "Freedom understood as choice is the opportunity to exercise the individual feeling of empowerment," ${ }^{13}$ which - in the case of a career - is reflected in proactivity and behaviour that promotes development and focuses on the satisfaction with one's professional life.

The essence of actions that promote development ${ }^{14}$ is taking up initiatives aimed at achieving a vision of some sort of an ideal status. The individual convinced of the legitimacy of this concept strives to achieve it in reality. In this perspective, one can successfully notice a clear reference to the issue of planning. The literature on the subject confirms that the ability to envisage future conditions and situations, closely bound to the temporal orientation, is one of the key features of human behaviour ${ }^{15}$, which proves extremely valuable in the subjective construction of one's career. An individual has the freedom not only to choose the career path, but also to progress and achieve these goals in the manner he or she prefers, which considerable affects the feeling of effectiveness and empowerment in action,

\footnotetext{
9 Z. Bauman, Career, op. cit., p. 20.

10 A. Bańka, Globalisation of the Labour Market and Careers Versus Processes of Social and Individual Identification, [in:] B. Kożusznik, M. Górnik - Durose (eds), Perspectives in Work Psychology, Katowice 2007, p. 56.

11 Z. Bauman, Career, Warszawa 1965, pp. 18-19.

12 Vide: U. Beck, Risk Society. On the Way to a Different Modernity, Warszawa 2002.

13 M. Jacyno, Individualism Culture, Warszawa 2007, p. 23.

${ }^{14}$ At this point, it should be mentioned that one of the most prominent Polish theoreticians dealing with pro-development issues was T. Zysk. (Vide: T. Zysk, Development Orientation, [in:] Social Orientation as an Element of Mentality, eds J. Reykowski, K. Skarżyńska, M. Ziółkowski, Poznań 1990, pp. 183-205.) References to this category can also be found in the works of J. Rykowski, J. Kozielecki, A. Bańka.

15 Vide: J. Reykowski, On the Issues of Psychology of Motivation, Warszawa 1970.
} 
as well as self-satisfaction. Proactivity, in turn, "is the behaviour which affects the environment indirectly." ${ }^{16}$ It is characteristic of individuals who take advantage of the opportunities created by the reality, which means they easily adapt to new conditions and increase their chance for professional success. Furthermore, they willingly generate change in that they take initiative independently of other people. Having proactive competences as well as those promoting development makes it possible for an individual to satisfy one's needs and aspirations drawing on the resources of subjective empowerment. The degree to which both these skills are developed considerably affects generating the meanings assigned to career by the individual.

The statement that the professional area is an incredibly important section of human existence may seem trivial, but a close inspection of this aspect will lead us to a few conclusions that are interesting from the cognitive point of view. The process of blurring borders between the professional and personal life is more and more often perceived. ${ }^{17}$ In the world of "careers without borders," the paths of professional development not only change their nature from vertical to horizontal, but sometimes are even considerably distorted. The division between "home and work" introduced in the period of the industrial revolution is now definitely shaken. What is more, P. Bohdziewicz notices a threat of the professional sphere dominating personal life; he claims that "the hidden context of the requirement to develop includes the demand for subordinating some aspect of personal life of an individual to the professional activity." ${ }^{18}$ Teleworking creates an opportunity to performs one's occupation also at home, whereas the growth of multinational organisations contributes to the increasing significance of mobility. Similarly, new forms of employment, such as: outsourcing, employee leasing, hiring people "for projects" considerably affect the quality and style of individual life. What is more,

${ }^{16}$ A. Bańka, Proactivity and Self-regulation Modes, Poznań - Warszawa 2005, p. 7.

17 Vide: L.A. Mainiero, S.E. Sullivan, The Opt-out Revolt: Why People Are Leaving Companies to Create Kaleidoscope Careers, California 2006, M.B. Arthur, The Boundaryless Career: A New Perspective for Organizational Inquiry, "Journal of Organizational Behavior," No. 4, Vol. 15, 1994., W. Bridges, Job Shift: How to Prosper in a Workplace Without Jobs, London 1995.

${ }_{18}$ P. Bohdziewicz, "Sharpening the Saw," i.e. Managers' Free Time, No. 2, 2003, p. 50. It is also worth noting that the type of work performed, or the career model being pursued, has a significant impact on the quality of an individual's family relations. According to P. Evans and F. Bartolome, they can take an independent form (occupational work and family life run independently of each other), an intertwining form (work and private life influence each other), a conflict (difficulties experienced at work are transferred to the sphere of family life and vice versa), a compensation (working life compensates for failures experienced privately and vice versa), an instrumental form (work is a means to implement family objectives), and an integration form (work is carried out in the domestic environment). A. Paszkowska - Rogacz, European Career Advisers and Their Workplace, Warszawa 2002, p. 42.) 
these forms are also significant for the professional identity they create, which means they also affect the individual satisfaction with work and involvement in one's own career. Therefore, in the context of these deliberations, it is worth concluding that reflection on one's own actions, also professional, is becoming a fundamental component of individual everyday activity.

Heterogeneity, multifaceted nature, fragmenting and complexity of the modern social organisation as well as the effect of these features on shaping career paths encourage the reflection on the essence of work. An express reference to this subject matter may be found in the words of K. Wenta, who claims that "the meaning of work is a value, i.e. something people appreciate, something that provides the meaning of life, the willingness to continue, to strive for something not only for yourself, but also for your nearest and dearest and for others." ${ }^{19}$ These words draw our attention to the multitude of contexts in which the category of work may be analysed: social, individual, existential, moral, biological, psychological, spiritual, legal, praxeological and educational. It turns out that work is in a way assigned to the individual life and has a considerable value as it entails development both as regards individual activity and social relations.

The multifaceted analysis of career and its significance for individuals also requires a closer look at the changes occurring within the nature of work itself. The need for permanent learning and the requirement of being flexible and quick in adjusting to new conditions in the work setting are important in shaping the meaning assigned by an individual to the category of career. In the face of considerable competition among corporations on the market, also the rivalry among candidates for work increases; those who want to find a job should be able to demonstrate high qualifications and competences and, most of all, the awareness of the resources they possess and the ability to present them accordingly. ${ }^{20}$ Individuals are less and less frequently bound to a specific place of work nowadays ${ }^{21}$, which follows from the increasingly popular category of contract work, which is also referred to as "psychological contract." 22 This is a conventional, informal relation, and it refers to the mutual expectations between the employee and the employer as regards

\footnotetext{
${ }^{19}$ K. Wenta, The Meaning of Work in Society of Knowledge, [in:] R. Gerlach (ed.), Human Work in the 21st century. Context - Challenges - Threats, Bydgoszcz 2008, p. 38.

${ }^{20}$ E.E Lawer, From Job-based to Competency-based Organizations, "Journal of Organizational Behaviour," No. 15, 1993, pp. 3-15.

${ }^{21}$ Vide: A. Bańka, Proactivity - Intentional Construction of the Future and Anticipating Achievement of Personal Goals Through Experience of Everyday Life, [in:] H. Wrona - Polańska, E.L. Czerniawska, L. Wrona (eds), Notes on Human Knowledge and Feeling, Kraków 2009, P. Bohdziewicz, Careers in Knowledge-based Economy (on the Example of IT Professional Group), Łódź 2008.

22 Vide: C. Argyris, Understanding Organizational Behavior, New York 1960.
} 
various aspects of work, which is significant for both the employee, who manages his/her own career and the employer who impacts the individual development. ${ }^{23}$ In this situation, loyalty towards an organisation and involvement in performing one's duties do not guarantee a successful career. ${ }^{24}$

Changes in the work settings also affect the way people perceive the phenomenon of career. Once we look at the understanding of career as proposed by $\mathrm{Ch}$. Handy, who claims that career is the constant search for the meaning of your role at workplace, ${ }^{25}$ we can notice not only that contemporary careers are a process, but also that individuals assign subjective meanings to it, as the phenomenon of career is being permanently defined and redefined. Consequently, the outcome of this process is supposed to bring satisfaction and the feeling of fulfilment. The author claims the satisfaction with individual professional activity is experienced in the financial standing (financial security), intellectual condition (motivation to act, challenges), emotional condition (the feeling of belonging and significance) and in the practical sense (everyday needs are met). ${ }^{26}$ Furthermore, the definition of an individual's professional role has three basic sources: direction (sets the purpose of actions, provides the meaning), continuity (timelessness of the chosen profession, which will last even after the individual has quit the job) and connectivity (between what is individual and social, identification with the community life). ${ }^{27}$ The researcher emphasises that the condition for finding your meaning in the world of work is permanent learning. You can find an express reference to the developmental perception of career in A. Watts's theoretical claims, according to which career is "a lifelong progression of an individual in learning and work." ${ }^{28}$ According to this academic researcher, this interpretation of the phenomenon is caused by the existence of the "career quake" - a process that calls for the redefinition of the career.

${ }^{23}$ J. Struges, N. Conway, D. Guest, A. Liefooghe, Managing the Career Deal: The Psychological Contract as a Framework for Understanding Career Management, Organizational Commitment and Work Behavior, “Journal Organizational Behavior," Vol. 26, No.7, 2008, pp. 821-838

${ }^{24}$ Vide: A. Bańka, Psychological Career Counselling, Poznań 2007, Idem, Career Capital - Conditions, Development and Adaptation to Organisational and Structural Changes of the Labour Market, [in:] Z. Ratajczak, A. Bańka, E. Turska (eds), Modern Occupational and Organisational Psychology, Katowice 2006, pp. 59-117.

25 Vide: Ch. Handy, The Age of Paradox, Boston 1994.

${ }^{26}$ D. Piotrowska (transl.), Piotrowska (transl.), Introduction, [in:] K. Borowiecka - Strug (ed.), Zarządzanie kariera (Career Management), Warszawa 2006, p. 11.

27 Ibidem

${ }^{28}$ Vide: A.G. Watts, Lifelong Career Development in an International Perspective: Theory, Policy and Practice, Keynote address to an International Networking Conference organized by the Foundation for Swiss Co-operation and held in Zurich on 14 September 2012, p. 1, available at: http://www.chgo.ch/repository/proxy/oifiles/10232/Querschnitt/Euroguidance/Vernetzung/2012_RF_llp_development_en.pdf (accessed on: 25.08.2015) 
There are many ways of discourse related to career - each of them focuses on a different aspect. In the considerations about the significance of career in the individual's life, we cannot neglect the subjective meaning assigned to career by the particular individual. Individual career paths are constructed as a result of the workings of various variables that define such paths, have their own external and internal, human connotations, yet their fundamental component of the individual professional biography is the element of choice. ${ }^{29}$ An individual has therefore a power and the skill to act intentionally, to create one's own lifestyle and specific professional identity for his or her career. An individual's professional activity, just like other spheres of life he or she experiences, is subject to individual evaluation, whereas the outcome is a set of meanings assigned to such activity. This relation is defined in terms of satisfaction with work, which affects the existence of professional success.

Initial exemplifications in this respect focused on the search for professional satisfaction based on matching the personality type to specific work environment. A pioneer of this type of research was J.L. Holland, who claimed that one can obtain satisfaction with one's career after finding a workplace, which makes it possible to meet one's needs and fulfil the relevant aspirations, values, develop skills or shape certain features of character. ${ }^{30}$ The researcher assumed that the match between the workplace and personality type promotes the permanence and lasting nature of professional choices, but also has a favourable effect on the individual's mental condition. ${ }^{31}$ The factors that condition the quality of the relation between both of the abovementioned spheres are consistency, differentiation, identity and congruence. ${ }^{32}$ The constructs distinguished by J.L. Holland have become a source of inspiration for a lot of research aimed at verifying their significance in individual professional development. The outcome of such research is often ambiguous. For example, the research carried out by G.D. Gottfredson and D.J. Lipsteia, ${ }^{33}$ by J.L. Holland, A.B. Sorensen, J.P. Clark, D.H.

\footnotetext{
29 Vide: A. Giddens., Modernity and Self-identity: Self and Society in the Late Modern Age, Warszawa 2012.

${ }^{30}$ J. Holland., Integrating Career Theory and Practice: The current Situation and Some Potential Remedies, [in:] M.L. Savickas, W.B. Walsh (eds.), Handbook of Career Counseling Theory and Practice, Palo Alto 1996, pp. 1-11.

31 Vide: J.L. Holland, Exploring Careers with a Typology: What We Have Learned and Some New Directions, "American Psychologist," 1996, p. 51.

32 Vide: Idem, Making Vocational Choices. A Theory of Vocational Personalities and Work Environments, Odessa 1997.

${ }_{33}$ G.D. Gottfredson, D.J. Lipstein., Using Personal Characteristics to Predict Parolee and Probationer Employment Stability, “Journal of Applied Psychology," No. 60, 1975, pp. 644-648.
} 
Nafziger and Z.D. Blum ${ }^{34}$ motivated the legitimacy of the thesis concerning the existence of a relationship between the consistency of the individuals and their chosen stable career models, whereas the exemplifications of T.D. Erwin ${ }^{35}$ and J.R. Latona ${ }^{36}$ did not corroborate this assumption. An interesting cognitive value can be found in the research related to the aspect of individual identity, because they have shown a correlation between the constancy of the objectives or preferences defined by the individual and the satisfaction with life and ${ }^{37}$ self-esteem. ${ }^{38}$ On the basis of these considerations, it may be concluded that satisfaction with one's career is largely conditioned by the individual degree of self-awareness, the knowledge about oneself and the ability to recognise one's own individual personality predispositions that affect the choice of a profession that would allow the individual to develop these features. ${ }^{39}$

Modern approach to professional life of an individual, to which the solution suggested by Mark L. Savicks can be included, attributes a constructive function for human existence to a career, considering it a main glue of all life spheres of a subject, also extraprofessional ones. The experiences gained in professional life carry connotations for the complete biography of an individual - they condition his or her aspirations related to the career as well as the process of creating one's own identity. ${ }^{40} \mathrm{~A}$ subjective manner of determining the career by a subject affects his/her lifestyle, needs, taken actions, the quality of entering into social roles, and interpretation of experienced events. ${ }^{41}$ Therefore, career has a specific

${ }^{34}$ J.L. Hollnad, A.B. Sorensen, J.P. Clark, D.H. Nafziger, Z.D.Blum., Applying an Occupational Classification to a Representative Sample of Work Histories, "Journal of Applied Psychology," No. 58, 1973, pp. 34-41.

35 T.D. Erwin, The Construct Validity to Holland's Construct of Consistency, "Journal of Vocational Behavior," No. 20, 1982, pp. 180-192.

36 J.R. Latona, Consistency of Holland Code and Its Relations to Persistence in College Major, "Journal of Vocational Behavior," No. 34, 1989, pp. 253-265

37 Vide: S.K. Olson, A.J. Johnston, J. Kunce, Validity of My Vocational Situation for Homemakers and Displaced Homemakers, "Measurement and Evaluation in Guidance," No. 18, 1985, pp. 17-25.

${ }^{38}$ Vide: N.E. Betz, D.A. Serling, Construct Validity of Fear of Commitment as an Indicator of Career Indecisiveness, "Journal of Career Assessment," No. 1, 1993, pp. 21-34.

39 In the context of the deliberations conducted here, it is worth noting that R. V. Dawis, L. H. Lofquist, D. J. Weiss were also analysing the issue of working environment compliance with the needs of an individual. Their research showed a correlation between the individual's expectations and gratifications offered by the working environment, which included above all usefulness at work and stability of employment. (R.V. Davis, The Theory of Work Adjustment as Convergent Theory, [in:] Savickas M.L., Lent R.W. (eds), Convergence in Career Development Theories, Palo Alto 1994, pp. 33-43.)

40 M.L. Savickas, Constructing Careers. A Developmental Theory of Vocational Behavior, [in:] D. Brown, L. Brooks, (red.), Career Choice and Development, San Francisco 2002, p. 43.

${ }^{41}$ Vide: J.G. Maree, Brief Overview of the Advancement of Postmodern Approaches to Career Counseling, "Journal for Psychology in Africa," No. 20(3), 2010, pp. 363-364. 
meaning for each individual, the meaning which depends on his/her life context. The opinions of D. E. Super on job satisfaction fit in the frame of this conceptualization. The researcher assumes that job and life satisfaction depend on the range within which an individual can use his/her abilities, interests, personality traits and values. They depend on the professional framework, workplace situation and lifestyle allowing to play roles which became proper ones through experiencing growth and exploration phases. ${ }^{42}$ In this proposal, the attention is paid to a processual and variable aspect of feeling satisfaction from the career. The question of driving forces embedded in a subject is not neglected, since the degree of freedom of actualizing the self-image conditions the quality of job experiences one has had.

The question of career satisfaction turns out to be cognitively important not only due to the aspect of job satisfaction but also because of the dimension related to self-realization of man. ${ }^{43}$ The subject responsible for the course of the development of his/her career, gets a chance to fulfil his/her aspirations and needs. Decisions and choices which are made, not always end successfully, and that is why the subject masters his/her persistence in pursuing goals, and learns to cope with negative emotions. ${ }^{44}$ Thus, career has its consequences for personality development. The traits of a subject, like the features of external environment, ${ }^{45}$ have an important impact on feeling job satisfaction. Satisfaction from your own professional success is not always the same as career satisfaction. A degree of career satisfaction is affected by certain motivation factors to which we can include recognition, achievements, possibilities of development, promotion, work content, and a range of responsibilities. ${ }^{46}$

Certainly, successful career is the issue which cannot be ignored in the context of this discussion. In the Dictionary of Polish Language, success is defined as an achievement of the defined objective; achievement of the thing to which most people aspire,

42 A. Paszkowska - Rogacz, Psychological Basis for Choosing a Profession. Overview of Theoretical Concepts, Warszawa 2003, pp. 84-85.

${ }^{43}$ Vide: K. Boniecka, H. Liberska, Work and Life Satisfaction in Adults in the Context of Changes on the Labour Market, [in:] H. Liberska, A. Malina, D. Suwalska - Barancewicz (eds), Functioning of Contemporary Youth in a Changing World, p. 107.

${ }^{44}$ J. Leary - Joyce, The Psychology of Success, Warszawa 2012, pp. 114-115.

45 These include, inter alia, the organizational climate, which contains such components as: conformism, responsibility, requirements, rewards, organization, sense of warmth and support, management. (A. Chudzicka-Czupała, Satisfaction with Work as a Component of the Quality of Contemporary Person's Life, "Chowanna," Vol. 1, No. 40, 2013, pp. 20-21.)

${ }^{46}$ A. Tokarska-Siudeja, Occupational Skills in Terms of Achieving Professional Satisfaction on the Changing Labour Market), [in:] W. Duda, D. Kukla, Contemporary Detarminants of the Labour Market, Częstochowa 2015, p. 95. 
e.g. a highly regarded position and authority in some field, popularity and money. ${ }^{47}$ Professional success can be understood as a display of professional mobility, and consequently social mobility, too, being a consequence of promotion. ${ }^{48}$ Objective indicators of success such as qualifications, prestige, received gratification lie at the heart of such understanding of success. Other suggested interpretations of this phenomenon focus on perceiving it in the light of the evaluation of achievements, plan implementation and realization of professional aspirations. The proposal of Edward Erazmus fits into this approach. According to him, a success means all predispositions which direct a man, including a pupil, student, worker, to achieve both, an important ideal of education and an ideal of abilities (activities) which, for an individual or a social group including an ethnic or religious group, is equal to taking the best place on the scale of values. It is equal to realizing the individual's potential capabilities. ${ }^{49}$ This opinion reveals a subjective dimension of success, and reaching the success is determined by the individual within the limits of individually defined "professional success." Terms which are self-defined by a subject will always be based on individual assumptions which can be totally different. ${ }^{50}$

Majority of research approaches regarding the aspect of professional success focus on the personality factors which have an essential meaning to the shape of the path of individual professional development, thereby for the individual motivation and professional engagement. Among other things, the influence of intellectual predispositions, the system of values and aspirations on the achieved professional success were analysed. ${ }^{11}$ The proposed findings predominantly focus on the process of perceiving and accepting your own professional activity, ${ }^{52}$ or subjective evaluation of the career, which, however, does not exclude the possibility of achieving socially recognized prestige. To the group of traits contributing to the success, Mateusz Kwiatkowski included, among other things, individual activity, self-reliance, risk taking, responsibility, ability of flexible and adequate participation in the job market, and creativity. ${ }^{53}$ Whereas, Ewa Grzeszczyk in her profile

\footnotetext{
${ }^{47}$ Dictionary of the Polish Language, Vol. 5, Warszawa 2007, p. 221.

${ }^{48}$ J. Leszkowicz - Baczyński., Concept and Success in Middle Class Environments, [in:] K.M. Słomczyński (ed.), Career and Success. Sociological Analyses, Zielona Góra - Warszawa 2007, p. 259.

${ }^{49}$ E. Erazmus, Education and Professional Success, Warszawa 1999, p. 11.

${ }^{50}$ J. Leary - Joyce, The Psychology of Success, Warszawa 2012, p. 32.

${ }^{51}$ Among others, research in this field was carried out by K. Janicka, K.M. Słomczyński, B.W Mach, W. Zaborowski, A. Firkowska - Mankiewicz, E. Grzeszczyk, M. Kwiatkowski, F. Byloka, J. Leszkowicz-Baczyńki.

${ }_{52}$ G. Bartkowiak, Man at Work. From Stress to Organizational Success, Warszawa 2009, p. 109.

${ }_{53}$ M. Kwiatkowski, The Man of Economic Success as a Role-model in the first Years of Systemic Transformation in Poland. A Study in Sociology of Morality, Zielona Góra 2000, p. 143.
} 
of success-generating traits listed a positive attitude to life, being success-oriented, education adjusted to present needs of the job market, self-esteem, ability to cope in difficult situations and face challenges, appropriate time management of work, identification with an organization, appreciation of financial gratification, persistence and determination, and acceptance of changes. ${ }^{54}$ The listed approaches highlight the importance of subjective activity on the way to individual success. Man engaged into his/her own professional development, for whom career is not indifferent, has a greater chance of satisfaction from the job done, and consequently, career satisfaction.

In Poland, Anna Firkowska-Mankiewicz was a pioneering explorer in this field. ${ }^{55}$ The researcher created a model of social success of man, distinguishing four components such as a material dimension, stratification and prestige dimension, emotional and affiliative dimension, and the dimension of self-realization. Within the first dimension, the attention is paid to financial gratifications obtained by the subject, material situation, and possessed goods. The dimension of stratification and prestige refers to higher education obtained by the individual as well as to social standing related to the career. Another dimension regards the quality of interpersonal relations, whose indicators are family, friends, marital happiness, reciprocated feeling, and intimate social contacts. While the self-realization dimension, which is characterized by the most subjective undertone, focuses on the values which have in common obtaining or realizing what satisfies a man, brings happiness, improves, develops, thus, for example, the achievement of life goals, realization of ambitions and dreams, satisfaction from oneself and life, self-improvement as well as intellectual, moral, emotional and physical development. ${ }^{56}$ It is worth mentioning that an individual career path of man is formed as a result of the influence of micro- (biological, psychological, personality and social traits of an individual), meso- (educational, vocational and cultural infrastructure of the society), and macro-structured factors (local, state and global economic, demographic, and political situation). ${ }^{57}$ These determinates affect the importance assigned to particular achievements of the subject.

It is also worth mentioning that there are empirical investigations oriented on the analysis of professional success from the viewpoint of external determinates such as job characteristics, social background, stratificational function of the soci-

\footnotetext{
54 E. Grzeszyk, Sukces. Success. American Models - Polish Reality, Warszawa 2003, pp. 211-228.

55 A. Firkowska-Mankiewicz, To Be Skilled... Careers and Life Successes of Warsaw Thirty-year-olds, Warszawa 1999.

${ }^{56}$ Ibidem, p. 18.

57 Ibidem.
} 
ety, inequality of chances, economic and demographic conditions of a country. The following should be included into the group of people interested in such an approach: Frederic Herzberg, Ricky W. Griffin, J. Richard Hackamn, Greg Oldham, Gerald Salancik, Jeffrey Preffer, Peter M. Blau, Duncan, William H. Sewell, Robert M. Hauser, and Włodzimierz Wesołowski. The external conditions regarding the subject were considered, among other things, when creating models of work whose dimensions determined the motivation content of an employee for fulfilling the appointed task, and the following were included: skill variety, task identity, task significance, autonomy and feedback..$^{58}$ Regularity, according to which the value assigned to an individual profession was affected by social factors, e.g. support of a work team or engagement of a supervisor, was also observed ${ }^{59}$ Researchers tried to distinguish factors responsible for professional promotion or demotion of people with the use of theories on social reproduction. Many modern studies are questioning the assumption that social background of a subject determines his/her professional position, however, we cannot forget that these factors indirectly affect professional success achieved by the subject.

In the context of this narration, a moral aspect of career (cultural acquiescence to success) is worth noticing. After the change in political and economic system in 1989, we can observe a process of redefining of commonly accepted systems of values in our country. The characteristics of this phenomenon are rendered by the words of Zygmunt Bauman who says that career is a drastic, painful, internally conflicted problem of modern morality. ${ }^{60}$ This process carries connotations also for the importance of career in human life. Many people participating in the job market can be rather disoriented due to the lack of consistency of rules governing the gratification for education, professional engagement, competences and qualifications. This results in shifting of the individual's orientation from external determinants of being toward internal determinants, ${ }^{61}$ which is expressed by self-management of the capital of one's own career, and frequently by assigning to it a pejorative meaning. This refers mainly to the question of revalidation in pursuing career. Modern reality is generating intensive stimuli which sometimes make an individual participate in a rat race. The main cause of such a situation should be seen in globalization which, to some extent, on the one hand universal-

\footnotetext{
58 J.R. Hackman, G. Oldham, R. Janson, K. Prudy, A New Strategy for Job Enrichment, "California Management Review," 17/1975, pp. 57-71.

${ }_{59}$ G.R. Salancij, J. Pfeffer, A Social Information Processing Approach to Job Attitudes and Task Design, “Administrative Science Quarterly," Vol. 23, No. 2, 1978, pp. 224-253.

${ }^{60}$ Z. Bauman, Kariera (Career), op. cit., p. 39.

${ }^{61}$ K. Obuchowski, An Intentional Person - How to Be Your Own Self, Poznań 2000, p. 62.
} 
izes the demand for success and promotion, and on the other hand, marginalizes "second-rate people," i.e. less industrious ones. The latter are not given the chance for achievements. ${ }^{62}$ All activities undertaken by a subject during competition are focused on achieving objective ${ }^{63}$ socially desired indicators of success (to lesser extent, on personal satisfaction). ${ }^{64}$ However, this does not change the fact that a subjective sense of career very often confirms an objective status of an individual, and constitutes a social response to this status. ${ }^{65}$

In the light of discussing the meanings attributed to career, it is impossible to ignore the meaning of work since it has an impact on the attitude of an individual to professional development. This reasoning should begin with looking at the etymology of the word "labour." In Latin, labour, laboris meant toil, strain, slog, industriousness, attention or hardship. ${ }^{66}$ They are identified with activities which require effort, and not necessarily bring satisfaction and give pleasure. Labour is given the role of the means to satisfy the needs and offer financial gratifications which provide for an individual. The kind of a profession and a professional function resulting from it not only significantly affects the subject's lifestyle but also constructs his/her social position. It has a pragmatic dimension which contributes to satisfying human life necessities, i.e. existential, material, consumption, living ones as well as the needs regarding fulfilment of aspirations or serving the development. ${ }^{67}$

${ }^{62}$ E. Erazmus, The Dilemmas of Successes, Promotions and Careers in Transition Period, Józefów 2011, p. 195.

${ }^{63}$ The research by A. Firkowska - Mankiewicz has showed, inter alia, that the respondents associate "success" mainly with financial success. (Vide: A. Firkowska - Mankiewicz., What is Life Success for the Contemporary Pole?, [in:] H. Domański, A. Rychard (red.), Elements of New Order, Warszawa 1997, pp. 303-330) In turn, E. Grzeszczyk has proved that personal success is the most important sphere of success, however - financial satisfaction is also often indicated by the respondents. (E. Grzeszczyk, Sukces. Success. American Models - Polish Reality, Warszawa 2003, p. 164.) The researchers, who have also highlighted the economic dimension of professional success, are K. Skarżyńska, K. Chmielewski, M.L Kohn and C. Schooler, J.M. Michalak.

${ }^{64}$ It is worth emphasizing that empirical investigations have indicated that the attitude to competition may become a barrier to success. (Vide: C. Sikorski, Ways to Success. Professionalism Versus Populist Organisational Culture, Warszawa 2007, p. 14.)

${ }^{65}$ R.L. Blankenship, Organizational Careers: An Interactionist Perspective, "The Sociological Quarterly," 14/1973, p. 89.

${ }^{66}$ K. Kumaniecki (ed.), Latin-Polish Dictionary, PWN, Warszawa 1984, p. 284. Any attempt to define the term "work" involves a danger of ahistoricism. Work is a phenomenon that accompanies people throughout the whole of period of mankind's development and is subject to permanent changes and causes them itself. Throughout history, not only has the meaning of work been changing, but also its essence; therefore, in the face of the discontinuity in its recognition, it cannot be defined clearly. (J. Tishner, Spór o istote pracy (Dispute over the Nature of Work), [in:] F. Adamski (ed.) Dispute over Values in Culture and Education, Kraków 1991, p. 53.)

${ }^{67}$ Vide: Z. Wiatrowski, Introduction to Occupational Pedagogy, Bydgoszcz 2005, p. 28. 
Labour can be also given a definitely more important meaning. Magdalena Pierunek notices it in her discussion, observing that labour permeates the whole life of a human who is involved into the contexture of social relations or prepares himself/herself for work, or carries it out, or withdraws from it. ${ }^{68}$ Therefore, it has procedural nature, like a professional career to which a subject is related throughout his/her whole life. Individuals prepare themselves for playing a certain professional role by taking up the employee obligations, and after having retired they stay in touch with work, which accompanies them in various forms. Experiences gained during professional development contribute not only to developing personal resources, which in consequence become a constructive element of the individual identity, but also to increasing his/her career capital. ${ }^{69}$

Human labour constitutes a form of a subject's activity which can be successfully included to a group of purposeful activities, aimed at specific results. Therefore, it remains in the field of social interest, within which it is constructed. The reasons of taking up the occupation by a man can be different and result from perceiving work in the categories of duty/task (instrumental value), or passion/ vocation (autotelic value).$^{70}$ Thus, labour can be the source of individual self-fulfilment, which significantly affects the level of engagement in performing labour activities. $^{71}$

The autotelic aspect of labour is expressed by the fact that it is a value in itself and the presumption due to which other values function, thus it is the source of values. $^{72}$ It is treated not only as the right of men which enables them to create decent living conditions ${ }^{73}$ but also as a factor that directs their lives. Labour is an

${ }_{68}$ M. Piorunek, The Course of a Person's Professional Life. Context of Cultural Transformation, Poznań 2009, p. 118.

${ }^{69}$ A. Bańka, Occupational and Organisational Psychology in the Postmodern Era. Challenges and Dilemmas of Continuity and Discontinuity in Development, [in:] B. Różnowski, M. Łaguna (eds), People at Work and in Organization. Psychological Perspective, Lublin 2011, pp. 28-29

${ }_{70}$ M. Piorunek, Bieg życia... (The Course of...), op. cit., p. 120.

${ }^{71}$ Among others, the research on the satisfaction with work has been conducted by: A. Zalewska, E. Diener, R.A. Emmons, R.J. Larsen, S. Griffin, E. Kasprzak, M.M. Salinas-Jimenez, J. Artes, J. Salinas-Jimenez, L. Thorpe, R. Loo, J.R. Burke, M. Koyuncu, J. Wolpin, T.A. Judge, C. Hurst, M. Łaguna, S.C. Currall, J.A. Towler, L. Kohn.

${ }^{72}$ W. Furmanek, Work as a Value in Contemporary Pedagogy, [in:] Human Work as a Category of Contemporary Pedagogy, ed. W. Furmanek, Rzeszów - Warszawa 2007. The autotelic dimension of work, which gives meaning to human existence, can also be seen in the theory of autocreation (Conf. Turos, 2006) and theory of motivation (Conf. Maslow, 1996). In these approaches, work makes it possible for people to have the sense of their own subjectivity, which constitutes a motivating factor for further activity.

73 Conf. J. Majka, Reflections upon Work Ethics, Tum, Wrocław 1997, p. 155. 
impulse mobilizing a subject to act, evoking the desire to be successful or to develop continually.

It allows to determine one's own position in the society, brings happiness and satisfaction from performed activities, affects physical, mental and social development. ${ }^{74}$ Moreover, it ensures the durability and existence of the society, not only due to its cultural nature but also cognitive identity-creating factors. It is worth emphasizing that a profession has an influence on self-esteem, dignity, and self-fulfilment. What is more, labour is an activity through which creativity and originality can be expressed, since it is a form of self-expression. Finally, labour informs about the status of man and is the source of pride and satisfaction. ${ }^{75}$

The changes in the world of work contribute to an increase in the role assigned to career. Professional activity is becoming not only one of the basic developmental goals of a subject, but frequently it turns out to be the measure of his/her achievements, social prestige and constitutes the source of happiness. Modern reality enables to manage an individual career, which more and more frequently occurs to be a necessity and requirement of the present job market. An individual is motivated to act for own best interest, encouraged to plan professional development, and thereby to increase his/her "market value." This regularity proves the importance of pro-activity for career, which can be found in the studies of Edward W. Morrison revealing the relationship between the activity of man articulated in the search for information and professional success articulated via getting the job, engagement in doing it and satisfaction as well as satisfactory "personal capital." ${ }^{\prime 6}$ Thus, professional career can be the source of life satisfaction of the individual, and the source of success, which confirms its emotional and evaluative importance. We should not ignore the sequence of personality changes which are brought by a new paradigm of career, and consequently its cognitive component. The sequence of personality changes affects the development of individual identity, thereby the manner the individual perceives himself/herself and is perceived by others. Career becomes an attribute of individual life, possessing constructive features not only for the sphere of professional life but also for the remaining spheres of existence.

\footnotetext{
${ }^{74}$ Conf. Z. Wiatrowski, Introduction to Occupational Pedagogy, op. cit., p. 25.

75 R. Parzęcki, Educational and Professional Plans of Young People at the Exploration Stage. Intentions. Choices. Reality, Włocławek 2003, p. 32.

${ }^{76}$ A. Bańka, Proactivity and..., op. cit., p. 32.
} 


\section{References}

Amstrong M., Zarządzanie Zasobami Ludzkimi (Human Resources Management), Kraków 2005.

Argyris C., Understanding Organizational Behavior, New York 1960.

Arthur M.B., The Boundaryless Career: A New Perspective for Organizational Inquiry, "Journal of Organizational Behavior," No. 4, Vol. 15, 1994.

Bańka A., Proaktywność a tryby samoregulacji (Proactivity and Self-regulation Modes), Poznań Warszawa 2005.

Bańka A., Jakość życia w psychologicznym doświadczeniu codzienności związanym $z$ rozwojem zawodowym, praca i bezrobociem (The Quality of Life in Psychological Experience of Everyday Life Related to Professional Development, Work and Unemployment), [in:] Bańka A., Derbis R. (ed.), Pomiar i poczucie jakości życia u aktywnych zawodowo oraz bezrobotnych (Measuring and Experiencing the Quality of Life in the Employed and the Unemployed), Poznań - Częstochowa 1995.

Bańka A., Globalizacja rynku pracy i kariery a procesy identyfikacji społecznej i indywidualnej (Globalisation of the Labour Market and Careers Versus Processes of Social and Individual Identification), [in:] Kożusznik B., Górnik - Durose M. (eds), Perspektywy psychologii pracy (Perspectives in Work Psychology), Katowice 2007.

Bańka A., Proaktywność - intencjonalne konstruowanie przyszłości i uprzedzające osiagniecie celów personalnych przez doświadczenie codzienności (Proactivity - Intentional Construction of the Future and Anticipating Achievement of Personal Goals Through Experience of Everyday Life), [in:] Wrona - Polańska H., Czerniawska E.L., Wrona L. (eds), Szkice o ludzkim poznawaniu i odczuwaniu (Notes on Human Knowledge and Feeling), Kraków 2009.

Bańka A., Psychologia pracy i organizacji w dobie ponowoczesności. Wyzwania i dylematy ciagłości i nieciagłości rozwoju (Occupational and Organisational Psychology in the Postmodern Era. Challenges and Dilemmas of Continuity and Discontinuity in Development), [in:] Różnowski B., Łaguna M. (red.), Człowiek w pracy i w organizacji. Perspektywa psychologiczna (People at Work and in Organization. Psychological Perspective), Lublin 2011.

Bańka A., Psychologiczne doradztwo karier (Psychological Career Counselling), Poznań 2007

Bańka A., Kapitał kariery - uwarunkowania, rozwój i adaptacja do zmian organizacyjnych oraz strukturalnych rynku pracy (Career Capital - Conditions, Development and Adaptation to Organisational and Structural Changes of the Labour Market), [in:] Ratajczak Z., Bańka A., Turska E. (eds), Wspótczesna psychologia pracy i organizacji (Modern Occupational and Organisational Psychology), Katowice 2006.

Bartkowiak G., Człowiek w pracy. Od stresu do sukcesu w organizacji (Man at Work. From Stress to Organizational Success), Warszawa 2009.

Bartkowiak G., Orientacja nastawiona na rozwój i uczenie się osób zatrudnionych w organizacji (Orientation Towards Development and Learning of Employees in Organisation), Poznan 1998.

Bauman Z., Kariera (Career), Warszawa 1965.

Beck U., Społeczeństwo ryzyka. W drodze do innej nowoczesności (Risk Society. On the Way to a Different Modernity), Warszawa 2002.

Betz N.E., Serling D.A., Construct Validity of Fear of Commitment as an Indicator of Career Indecisiveness, "Journal of Career Assessment," No. 1, 1993.

Blankenship R.L., Organizational Careers: An Interactionist Perspective, "The Sociological Quarterly," 14/1973.

Bohdziewicz P., "Ostrzenie pity”, czyli czas wolny menadżerów ("Sharpening the Saw," i.e. Managers' Free Time), "Zarządzanie Zasobami Ludzkimi,” No. 2, 2003. Paszkowska - Rogacz A., Warsztat pracy europejskiego doradcy kariery zawodowej (European Career Advisers and Their Workplace), Warszawa 2002. 
Bohdziewicz P., Kariery zawodowe w gospodarce opartej na wiedzy (na przykładzie grupy zawodowej informatyków) [Careers in Knowledge-based Economy (on the Example of IT Professional Group)], Łódź 2008.

Boniecka K., Liberska H., Zadowolenie z pracy i satysfakcja z życia u dorostych w kontekście przemian na rynku pracy (Work and Life Satisfaction in Adults in the Context of Changes on the Labour Market), [in:] Liberska H., Malina A., Suwalska - Barancewicz D. (eds), Funkcjonowanie współczesnych młodych ludzi w zmieniajacym się świecie Functioning of Contemporary Youth in a Changing World).

Borowiecka - Strug K. (red.), Zarządzanie kariera (Career Management), Warszawa 2006.

Bridges W., Job Shift: How to Prosper in a Workplace Without Jobs, London 1995.

Chudzicka-Czupała A., Zadowolenie z pracy jako komponent jakości życia współczesnego człowieka (Satisfaction with Work as a Component of the Quality of Contemporary Person's Life), "Chowanna," Vol. 1, No. 40, 2013.

Cybal-Michalska A., Świat, w którym "kariera robi karierę" - o satysfakcji z kariery i poczuciu zawodowego sukcesu (The World in Which "Career Has a Career" - the World of Satisfaction with Career and Professional Success), "Studia Edukacyjne," No. 26, 2013.

Davis R.V., The Theory of Work Adjustment as Convergent Theory, [in:] Savickas M.L., Lent R.W. (eds), Convergence in Career Development Theories, Palo Alto 1994.

Duda W., Kukla D., Kariera zawodowa wobec postęujacych przemian pracy (A Career in the Face of Progressing Transformations at Work), Częstochowa 2010.

Erazmus E., Dylematy sukcesów, awansów i karier w okresie transformacji (The Dilemmas of Succesess, Promotions and Careers in Transition Period), Józefów 2011.

Erazmus E., Edukacja a sukces zawodowy (Education and Professional Success), Warszawa 1999.

Erwin T.D., The Construct Validity to Holland's Construct of Consistency, "Journal of Vocational Behavior," No. 20, 1982.

Firkowska - Mankiewicz A., Czym jest sukces życiowy dla współczesnego Polaka? (What is Life Success for the Contemporary Pole?), [in:] Domański H., Rychard A. (eds), Elementy nowego ładu (Elements of New Order), Warszawa 1997

Firkowska-Mankiewicz A., Zdolnym być... Kariery i sukces życiowy warszawskich trzydziestolatków(To Be Skilled... Careers and Life Successes of Warsaw Thirty-year-olds), Warszawa 1999.

Furmanek W., Praca jako wartość w pedagogice współczesnej (Work as a Value in Contemporary Pedagogy), [in:] Furmanek W. (ed.) Praca człowieka jako kategoria współczesnej pedagogiki (Human Work as a Category of Contemporary Pedagogy), Rzeszów - Warszawa 2007

Giddens A., Modernity and Self-identity: Self and Society in the Late Modern Age, Warszawa 2012.

Gottfredson G.D., Lipstein D.J., Using Personal Characteristics to Predict Parolee and Probationer Employment Stability, "Journal of Applied Psychology," No. 60, 1975.

Grzeszyk E., Sukces. Amerykańskie wzory - polskie realia (Success. American Models - Polish Reality), Warszawa 2003.

Hackman J.R., Oldham G., Janson R., Prudy K., A New Strategy for Job Enrichment, “California Management Review," 17/1975.

Handy Ch., The Age of Paradox, Boston 1994.

Holland J., Integrating Career Theory and Practice: The current Situation and Some Potential Remedies, [In:] Savickas M.L., Walsh W.B. (ed.), Handbook of Career Counseling Theory and Practice, Palo Alto 1996.

Holland J.L., Exploring Careers with a Typology: What We Have Learned and Some New Directions, "American Psychologist," 1996.

Holland J.L., Making Vocational Choices. A Theory of Vocational Personalities and Work Environments, Odessa 1997. 
Hollnad J.L., Sorensen A.B., Clark J.P., Nafziger D.H., Blum Z.D., Applying an Occupational Classification to a Representative Sample of Work Histories, "Journal of Applied Psychology," No. 58, 1973.

Jacyno M., Kultura indywidualizmu (Individualism Culture), Warszawa 2007.

Kargulowa A., O teorii i praktyce poradnictwa. Odmiany poradoznawczego dyskursu (About the Theory and Practice of Counselling. Varieties of Counselling Discourse), Warszawa 2007.

Kasprzak E., Poczucie jakości życia pracowników realizujących różne wzory kariery zawodowej (The Sense of Quality of Life for Employees with Different Career Patterns), Bydgoszcz 2013

Klimkowska K., Orientacja na sukces zawodowy studentów kończących studia translatorskie (Orientation Towards Professional Success of Students Graduating from Translation Studies), Lublin 2013.

Kumaniecki K. (red.), Słownik łacińsko - polski (Latin-Polish Dictionary), PWN, Warszawa 1984

Kwiatkowski M., Człowiek sukcesu ekonomicznego jako wzór osobowy w pierwszych latach transformacji systemowej $w$ Polsce. Studium z socjologii moralności (The Man of Economic Success as a Role-model in the first Years of Systemic Transformation in Poland. A Study in Sociology of Morality), Zielona Góra 2000.

Lanthaler W., Zugmann J., Akcja JA. Nowy sposób myślenia o karierze (ME Campaigne. A New Way of Thinking About Career), Warszawa 2000.

Latona J.R., Consistency of Holland Code and Its Relations to Persistence in College Major, "Journal of Vocational Behavior," No. 34, 1989.

Lawer E.E., From Job-based to Competency-based Organizations, "Journal of Organizational Behaviour," No. 15, 1993.

Leary - Joyce J., The Psychology of Success, Warszawa 2012.

Leszkowicz - Baczyński J.., Koncepcja i przejawy sukcesu w środowiskach klasy średniej (Concept and Success in Middle Class Environments), [in:] Słomczyński K.M. (ed.), Kariera i sukces. Analizy socjologiczne (Career and Success. Sociological Analyses), Zielona Góra - Warszawa 2007.

Mainiero L.A., Sullivan S.E., The Opt-out Revolt: Why People Are Leaving Companies to Create Kaleidoscope Careers, California 2006.

Majka J., Rozważania o etyce pracy (Reflections upon Work Ethics), Tum, Wrocław 1997.

Maree J.G., Brief Overview of the Advancement of Postmodern Approaches to Career Counseling, "Journal for Psychology in Africa," No. 20(3), 2010.

Obuchowski K., Człowiek intencjonalny, czyli o tym, jak być soba (An Intentional Person - How to Be Your Own Self), Poznań 2000

Olson S.K., Johnston A.J., Kunce J.., Validity of My Vocational Situation for Homemakers and Displaced Homemakers, "Measurement and Evaluation in Guidance," No. 18, 1985.

Parzęcki R., Plany edukacyjno - zawodowe młodzieży w stadium eksploracji. Zamierzenia. Wybory. Realia (Educational and Professional Plans of Young People at the Exploration Stage. Intentions. Choices. Reality), Włocławek 2003.

Paszkowska - Rogacz A., Psychologiczne podstawy wyboru zawodu. Przeglad koncepcji teoretycznych (Psychological Basis for Choosing a Profession. Overview of Theoretical Concepts), Warszawa 2003.

Piorunek M., Bieg życia zawodowego człowieka. Kontekst transformacji kulturowych (The Course of a Person's Professional Life. Context of Cultural Transformation), Poznań 2009.

Reykowski J., Z zagadnień psychologii motywacji (On the Issues of Psychology of Motivation), Warszawa 1970.

Salancij G.R., Pfeffer J., A Social Information Processing Approach to Job Attitudes and Task Design, "Administrative Science Quarterly," Vol. 23, No. 2, 1978.

Savickas M.L., Constructing Careers. A Developmental Theory of Vocational Behavior, [in:] Brown D., Brooks L., (eds), Career Choice and Development, San Francisco 2002.

Sikorski C., Drogi do sukcesu. Profesjonalizm contra populistyczna kultura organizacyjna (Ways to Success. Professionalism Versus Populist Organisational Culture), Warszawa 2007. 
Słomczyński K., Kariera i sukces. Analizy socjologiczne (Career and Success. Sociological Analyses), Zielona Góra 2007

Słownik języka polskiego (Dictionary of the Polish Language), Vol. 5, Warszawa 2007.

Struges J., Conway N., Guest D., Liefooghe A., Managing the Career Deal: The Psychological Contract as a Framework for Understanding Career Management, Organizational Commitment and Work Behavior, "Journal Organizational Behavior," Vol. 26, No.7, 2008.

Suchar M., Modele kariery. Przewidywanie kolejnego kroku (Career models. Predicting the next step), Warszawa 2010.

Tishner J., Spór o istotę pracy (Dispute over the Nature of Work), [in:] Adamski F. (ed.) Spór o wartości w kulturze i wychowaniu (Dispute over Values in Culture and Education), Kraków 1991.

Tokarska-Siudeja A., Umiejętności zawodowe człowieka w aspekcie osiagania satysfakcji zawodowej na zmieniajacym rynku pracy (Occupational Skills in Terms of Achieving Professional Satisfaction on the Changing Labour Market), [in:] Duda W., Kukla D., Wspótczesne uwarunkowania rynku pracy (Contemporary Detarminants of the Labour Market), Częstochowa 2015.

Walsh W.B., Savickas M.L., Hartung P.J., Handbook of Vocational Psychology. Theory, Research, and Practice, $4^{\text {th }}$ Edition, Routledge, United Kingdom 2013.

Wenta K., Sens pracy w spoteczeństwie wiedzy (The Meaning of Work in Society of Knowledge), [in:] Gerlach R. (ed.), Praca człowieka w XXI wieku. Konteksty - wyzwania - zagrożenia (Human Work in the 21st century. Context - Challenges - Threats), Bydgoszcz 2008.

Wiatrowski Z., Podstawy pedagogiki pracy (Introduction to Occupational Pedagogy), Bydgoszcz 2005.

Zysk T., Orientacja prorozwojowa (Development Orientation), [in:] Orientacje społeczne jako element mentalności (Social Orientation as an Element of Mentality), Reykowski J., Skarżyńska K., Ziółkowski M. (eds), Poznań 1990. 